\title{
KEMAMPUAN PEMECAHAN MASALAH DALAM MENYELESAIKAN MASALAH ALJABAR LINEAR PADA PEMBELAJARAN DARING UNIVERSITAS BORNEO TARAKAN
}

\author{
Ferryansyah $^{1}$, Liswiki Chandra ${ }^{2}$ \\ ${ }^{1}$ Jurusan Pendidikan Matematika, FKIP UBT \\ ${ }^{2}$ Jurusan Pendidikan Matematika, FKIP UBT \\ ${ }^{1}$ vrsyah.math@gmail.com \\ liswikichandra@gmail.com
}

\begin{abstract}
This study aims to describe problem solving abilities in solving linear algebra problems of students majoring in Mathematics Education at UBT in online learning, for each indicator of mathematical problem solving ability. The type of research used in this research is descriptive with a quantitative approach. The data collection method uses a problem-solving ability test in solving linear algebra problems in the form of descriptions. The test of mathematical problem solving ability is carried out online using the Zoom and WhatsApp applications. The sample in this study amounted to 73 students who were taken using a saturated sampling technique. The results of this study indicate that the indicator for understanding the problem is in the high category with an average value of 77.35 or with a percentage value of $35.72 \%$, the indicator for planning completion is in the medium category with an average value of 61.73 or with a percentage value of $28.51 \%$, the indicator carries out completion. classified in the medium category with an average value of 42.83 or with a percentage value of $19.78 \%$, and the re-examination indicator is classified as a medium category with an average value of 34.61 or a percentage value of $15.98 \%$.
\end{abstract}

Keywords: Mathematical Problem Solving Ability, Online Learning.

\begin{abstract}
Abstrak
Penelitian ini bertujuan untuk mendeskripsikan kemampuan pemecahan masalah dalam menyelesaikan masalah aljabar linear mahasiswa jurusan Pendidikan Matematika UBT pada pembelajaran daring, untuk setiap indikator kemampuan pemecahan masalah matematika. Jenis penelitian yang digunakan dalam penelitian ini adalah deskriptif dengan pendekatan kuantitatif. Metode pengumpulan data menggunakan tes kemampuan pemecahan masalah dalam menyelesaikan masalah aljabar linear berupa uraian. Adapun pemberian tes kemampuan pemecahan masalah matematika dilakukan secara daring menggunakan aplikasi Zoom dan WhatsApp. Sampel dalam penelitian ini berjumlah 73 mahasiswa yang diambil menggunakan teknik sampling jenuh. .Hasil penelitian ini menujukkan bahwa untuk indikator memahami masalah tergolong kategori tinggi dengan nilai rata-rata sebesar 77.35 atau dengan nilai persentase $35.72 \%$, indikator merencanakan penyelesaian tergolong kategori sedang dengan nilai rata-rata sebesar 61.73 atau dengan nilai persentase $28.51 \%$, indikator melaksanakan penyelesaian tergolong kategori sedang dengan nilai rata-rata sebesar 42.83 atau dengan nilai persentase $19.78 \%$, dan indikator memeriksa kembali tergolong kategori sedang dengan nilai rata-rata sebesar 34.61 atau dengan nilai persentase $15.98 \%$.
\end{abstract}

Kata kunci: Kemampuan Pemecahan Masalah Matematika, Pembelajaran Daring.

Cara Menulis Sitasi: Ferryansyah., \&, Chandra, Liswiki. (2021). Kemampuan Pemecahan Masalah dalam Menyelesaikan Masalah Aljabar Linear Mahasiswa Jurusan Pendidikan Matematika UBT pada Pembelajaran Daring. Mathematic Education and Aplication Journal, volume 03 no.2, halaman 9-16

Pelajaran matematika merupakan pelajaran yang ada pada setiap jenjang Pendidikan. Sehingga matematika merupakan salah satu bidang studi yang memiliki peranan penting dalam dunia pendidikan. Salah satu pelajaran matematika yang ada pada tingkat perguruan tinggi adalah mata 
kuliah Aljabar Linear. Ketika belajar Aljabar Linear mahasiswa akan sering menemukan permasalahan-persamaan aljabar. Menurut Aini (2014:159) bahwa masalah aljabar adalah suatu soal/pertanyaan yang berhubungan dengan simbol, variabel dan persamaan yang secara penyelesaian tidak langsung mempunyai aturan atau alogaritma yang segera dapat di selesaikan untuk menentukan jawabannya. Dengan demikian mahasiswa dilatih untuk berpikir logis dan kritis dalam memecahkan masalah dengan objek-objek yang abstrak dalam menyelesaikan masalah pada mata kuliah Aljabar Linear.

Kemampuan memecahkan masalah pada dasarnya amat diperlukan peserta didik, seperti yang dikemukakan oleh Branca dalam (Effendi, 2012:2) bahwa pemecahan masalah merupakan jantungnya matematika. Selajan dengan hal tersebut Ulya dkk (2014) mengungkapkan bahwa Matematika tidak bisa dipisahkan dengan pemecahan masalah. Misu (2014) mengungkapkan bahwa pemecahan masalah merupakan bagian dari kurikulum matematika yang sangat penting karena dalam proses pembelajaran dan penyelesaian, peserta didik mengunakan pengetahuan dan keterampilan yang telah dimiliki untuk diterapkan ke pemecahan masalah. Dengan berbekal kemampuan memecahkan masalah yang diperoleh dari pembelajaran Aljabar Linear, diharapkan mahasiswa mampu menghadapi dan menyelesaikan masalah hidupnya sendiri.

Kemampuan pemecahan masalah dapat dicapai dengan memanfaatkan berbagai macam pembelajaran baik tatap muka maupun pembelajaran lainnya. Pembelajaran tatap muka adalah pembelajaran yang berupa proses intraksi antara peserta didik, materi pembelajaran, guru dan lingkungan (Permendiknas Nomor 22 tahun 2006). Dalam masa pendemi Covid 19 seperti sekarang, pembelajaran daring sebagai solusi yang dapat digunakan. Pembelajaran daring pada masa Covid-19 sudah diterapkan diberbagai sekolah maupun universitas, salah satunya di Universitas Borneo Tarakan (UBT). Pembelajaran daring di universitas tersebut menggunakan aplikasi seperti ELearning, WhatsApp, dan aplikasi daring lainnya.

E-Learning merupakan teknologi pembelajaran yang berprean penting untuk siswa mengakses pembelajaran jarak jauh (Nortving, 2014). Lane dalam (Kurniawan dkk, 2020) menyatakan bahwa E-Learning merupakan sumber informasi online yang sangat berguna, karena dengan pembelajaran E-Learning peserta didik tidak harus melakukan tatap muka. Salah satu pendukung E-Learnig adalah aplikasi WhatsApp yang digunakan untuk mengirimkan berupa link materi, video, dan membentuk kelompok belajar dengan chatting (Hidayatullah, 2018: 9).

Permasalahan yang terjadi pada masa pembelajaran daring diperoleh bahwa nilai mata kuliah Aljabar Linear semester ganjil 2020/2021 di Jurusan Pendidikan Matematika, Universitas Borneo Tarakan masih rendah. Diperoleh rata-rata nilai Penilaian Akhir Semester (PAS) Kelas A1 dan A2 masih di bawah 50. Salah satu contoh jawaban berikut mengindikasikan pemahaman masalah, langkah pengerjaan, dan kesimpulan yang masih tidak sesuai. 


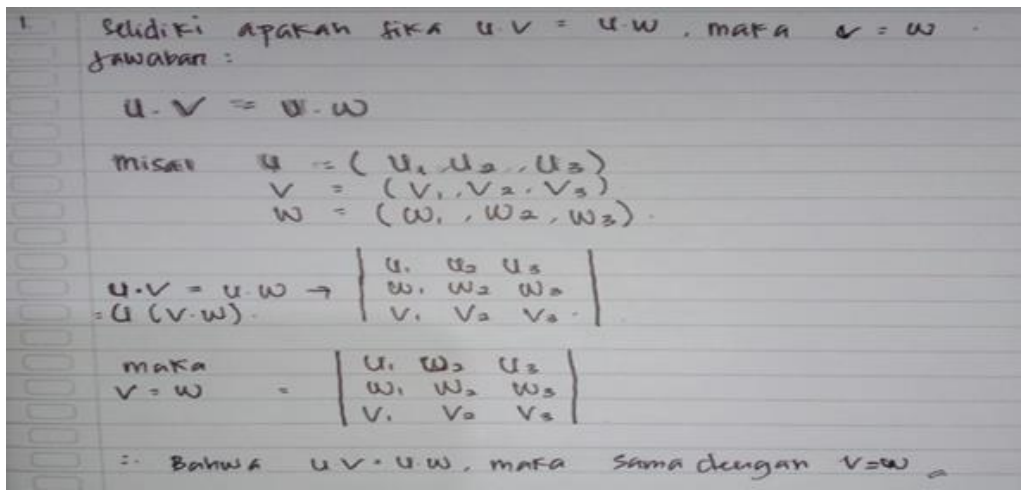

Gambar 1. Contoh jawaban soal aljabar linear

Menurut penelitian Zahra (2017) tentang kemampuan menyelesaikan masalah Aljabar linear pada mata kuliah Aljabar Linear, menunjukkan bahwa kemampuan mahasiswa matematika universitas muhammadiyah Surakarta dalam menyelesaikan sistem persamaan linear yang berkaitan dengan kontekstual yaitu, mahasiswa tidak mengidentifikasi yang diketahui dan yang ditanyakan terlebih dahulu melainkan langsung melakukan perhitungan. Sebagian besar mahasiswa tidak menggunakan strategi tertentu dalam memecahkan masalah. Pada akhir jawaban, mahasiswa juga tidak membuat kesimpulan dari hasil yang diperoleh.

Oleh karena itu, berkaitan dengan kemampuan pemecahann masalah mahasiswa pendidikan matematika dalam menyelesaikan masalah pada mata kuliah Aljabar Linear di FKIP Universitas Borneo Tarakan dan hasil penelitian dari Zahra, penelti bermaksud mendskripsikan kemampuan pemecahan masalah dalam menyelesaikan aljabar linear pada pembelajaran daring di Universitas Borneo Tarakan. Penelitian ini diharapkan menjadi bahan evaluasi dalam mengajarkan mata kuliah Aljabar Linear di FKIP Universitas Borneo Tarakan.

\section{METODE}

Jenis penelitian yang digunakan adalah penelitian deskriptif dengan pendekatan kuantitatif yaitu untuk memperoleh deskripsi mengenai kemampuan pemecahan masalah dalam menyelesaikan masalah aljabar linear mahasiswa jurusan Pendidikan Matematika UBT pada pembelajaran daring. Penelitian ini akan dilaksanakan di Jurusan Pendidikan Matematika, FKIP Universitas Borneo Tarakan dengan subjek penelitian mahasiswa Jurusan Pendidikan Matematika Semester genap 2020/2021 dengan teknik sampling jenuh. Teknik analisis berupa tes yang digunakan untuk mengukur kemampuan pemecahan masalah matematika siswa dalam pembelajaran daring. Data hasil tes dianalisis berdasarkan pedoman penilaian yang telah dibuat peneliti. Pedoman penilaian hasil tes siswa didasarkan pada indikator kemampuan pemecahan masalah matematika. Teknik analisis dilakukan dengan beberapa tahapan antara lain: (a) Pemberian nilai, (b) Pengkategorian berdasarkan kemampuan pemecahan masalah matematika, (c) Menghitung rata - rata untuk setiap kategori. 


\section{HASIL DAN PEMBAHASAN}

Pengolahan data dengan microsoft exel untuk melihat Kemampuan Pemecahan Masalah Matematika dalam Menyelesaikan Aljabar Linear Untuk Setiap Indikator KPMM sebagai berikut :

Tabel 1. Kemampuan Pemecahan Masalah Matematika dalam Menyelesaikan Aljabar Linear Untuk Setiap Indikator KPMM

\begin{tabular}{|cccc|}
\hline $\begin{array}{c}\text { Indikator Kemampuan } \\
\text { Pemecahan Masalah } \\
\text { Matematika }\end{array}$ & Rata-rata & $\begin{array}{c}\text { Kategori } \\
\text { Rata-rata }\end{array}$ & Persentase \\
\hline Memahami Masalah & 77.35 & Tinggi & 35.75 \\
Merencanakan Penyelesaian & 61.73 & Sedang & 28.51 \\
Melaksanakan Penyelesaian & 42.83 & Sedang & 19.78 \\
Memeriksa Kembali & 34.61 & Sedang & 15.98 \\
\hline
\end{tabular}

Tabel 1 menunjukkan pada indikator memahami masalah dengan nilai rata-rata sebesar 77.35 tergolong kategori tinggi dan memiliki persentase 35.75\%. Selanjutnya indikator merencanakan penyelesaian, memperoleh nilai rata-rata sebesar 61.73 tergolong kategori sedang dan memiliki persentase $28.51 \%$. Kemudian indikator melaksanakan penyelesaian dengan rata-rata sebesar 42.83 tergolong kategori sedang dan memiliki persentase $19.78 \%$. Dan indikator memeriksa kembali memperoleh nilai rata-rata sebesar 34.61 tergolong kategori sedang dan memiliki persentase $15.98 \%$.

Tabel 2. Kemampuan Pemecahan Masalah Matematika Siswa Per Indikator Berdasarkan Kategori Kemampuan Pemecahan Masalah Matematika

\begin{tabular}{|c|c|c|c|c|c|c|c|c|c|c|}
\hline \multirow{2}{*}{ No } & \multirow{2}{*}{ Indikator KPMM } & \multicolumn{9}{|c|}{ Kategori KPMM } \\
\cline { 3 - 11 } & & \multicolumn{3}{|c|}{ Tinggi } & \multicolumn{3}{c|}{ Sedang } & \multicolumn{3}{c|}{ Rendah } \\
\cline { 3 - 12 } 1 & $\begin{array}{c}\text { Memahami } \\
\text { masalah }\end{array}$ & 95.8 & $\mathrm{~S}$ & 32.5 & 75.33 & $\mathrm{~S}$ & 40.12 & 37.22 & $\mathrm{~S}$ & 36.02 \\
\hline 2 & $\begin{array}{c}\text { Merencanakan } \\
\text { penyelesaian }\end{array}$ & 85.19 & $\mathrm{~S}$ & 28.89 & 52.89 & $\mathrm{~S}$ & 28.17 & 30 & $\mathrm{~S}$ & 29.03 \\
\hline 3 & $\begin{array}{c}\text { Melaksanakan } \\
\text { penyelesaian }\end{array}$ & 62.22 & $\mathrm{~S}$ & 21.11 & 34 & $\mathrm{~S}$ & 18.11 & 20.56 & $\mathrm{~S}$ & 19.89 \\
\hline & $\begin{array}{c}\text { Memeriksa } \\
\text { kembali }\end{array}$ & 51.6 & $\mathrm{~S}$ & 17.5 & 25.56 & $\mathrm{~S}$ & 13.61 & 15.56 & $\mathrm{~S}$ & 15.05 \\
\hline
\end{tabular}




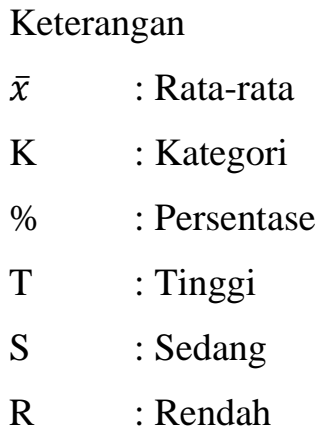

Berdasarkan tabel 2 dapat dilihat bahwa mahasiswa yang memiliki kategori kemampuan pemecahan masalah matematika dalam menyelesaikan aljabar linear tinggi memperoleh nilai rata-rata sebesar 95.80 tergolong kategori tinggi dan memiliki persentase $32.50 \%$ pada indikator 1 , memperoleh nilai rata-rata sebesar 85.19 tergolong kategori sedang dan memiliki persentase $28.89 \%$ pada indikator 2, memperoleh nilai rata-rata sebesar 62.22 tergolong kategori sedang dan memiliki persentase $21.11 \%$ pada indikator 3, dan memperoleh nilai rata-rata sebesar 51.60 tergolong kategori sedang dan memiliki persentase $17.50 \%$ pada indikator 4 .

Sedangkan, mahasiswa yang memiliki kemampuan pemecahan masalah matematika sedang dalam menyelesaikan masalah aljabar linear memperoleh nilai rata-rata sebesar 75.33 tergolong kategori sedang dan memiliki memiliki persentase $40.12 \%$ pada indikator 1 , memperoleh nilai ratarata sebesar 52.89 tergolong kategori sedang dan memiliki persentase $28.17 \%$ pada indikator 2, memperoleh nilai rata-rata sebesar 34.00 tergolong kategori sedang dan memiliki persentase $18.11 \%$ pada indikator 3, dan memperoleh nilai rata-rata sebesar 25.56 tergolong kategori sedang dan memiliki persentase $13.61 \%$ pada indikator 4 .

Sedangkan, mahasiswa yang memiliki kemampuan pemecahan masalah matematika rendah dalam menyelesaikan masalah aljabar linear memperoleh nilai rata-rata sebesar 37.22 tergolong kategori sedang dan memiliki persentase $36.02 \%$ pada indikator 1 , memperoleh nilai rata-rata sebesar 30.00 tergolong kategori sedang dan memiliki persentase $29.03 \%$ pada indikator 2, memperoleh nilai rata-rata sebesar 20.56 tergolong kategori sedang dan memiliki persentase $19.89 \%$ pada indikator 3 , dan memperoleh nilai rata-rata sebesar 15.56 tergolong kategori sedang dan memiliki persentase $15.05 \%$ pada indikator 4 .

Penelitian ini dilaksanakan pada mahasiswa semester 4 di Universitas Borneo Tarakan dengan tujuan untuk mengetahui tingkat kemampuan pemecahan masalah matematika mahasiswa dalam menyelesaikan masalah aljabar linear melalui pembelajaran daring. Data yang menunjukkan kemampuan pemecahan masalah matematika mahasiswa diperoleh melalui tes yang berbentuk essai dengan soal berjumlah 5 butir. Materi yang digunakan dalam penelitian ini yaitu Aljabar Linear, materi tersebut diajarkan secara daring menggunakan aplikasi Zoom dan WhatsApp. Pemberian tes kemampuan pemecahan masalah matematika siswa dilakukan secara daring yaitu, menggunakan 
aplikasi Zoom dan WhatshApp. Pada penelitian ini terdapat sampel sebanyak 73 mahasiswa yang terdiri dari 2 kelas.

Adapun hasil deskripsi Kemampuan Pemecahan Masalah Matematika Siswa Melalui Pembelajaran Daring Berdasarkan Indikator Pemecahan Masalah sebagai berikut:

\section{a. Memahami Masalah}

Tabel 1 menunjukkan pada indikator memahami masalah dengan nilai rata-rata sebesar 77.35 tergolong kategori tinggi dan memiliki persentase 35.75\%. Artinya, beberapa mahasiswa sudah mampu memahami masalah. Ada juga beberapa mahasiswa yang belum menuliskan apa yang diketahui dan apa yang ditanyakan kerena belum mampu membedakan kedua hal tersebut.

Tabel 2 kemampuan pemecahan masalah matematika siswa untuk indikator memahami masalah pada kategori tinggi memperoleh nilai rata-rata 95.80 tergolong kategori tinggi dan memiliki persentase $32.50 \%$. Artinya siswa dapat memahami masalah dengan baik. Siswa sudah mampu menuliskan apa yang diketahui dan apa yang ditanyakan dengan tepat dan lengkap. Selanjutnya kemampuan pemecahan masalah matematika siswa pada kategori sedang memperoleh nilai rata-rata 75.33 tergolong kategori sedang dan memiliki persentase 40.12\%. Dan kemampuan pemecahan masalah matematika siswa pada kategori rendah memperoleh nilai rata-rata 37.22 tergolong kategori sedang dan memiliki persentase $36.02 \%$. Artinya, untuk kedua kategori tersebut mahasiswa sudah mampu memahami masalah dengan cukup baik. Mahasiswa mampu menuliskan yang diketahui dan ditanyakan atau setengah dari jawaban yang seharusnya.

\section{b. Merencanakan Penyelesaian}

Tabel 1 menunjukkan pada indikator merencanakan penyelesaian dengan nilai rata-rata sebesar 61.73 tergolong kategori sedang dan memiliki pencapain perentase $28.51 \%$. Artinya secara keseluruhan mahasiswa sudah mampu menentukan atau membuat strategi yang akan digunakan dalam menyelesaikan masalah.

Tabel 2 kemampuan pemecahan masalah matematika mahasiswa untuk indikator merencanakan penyelesaian pada tingkat kategori tinggi memperoleh nilai rata-rata 85.19 tergolong kategori sedang dan memiliki persentase $28.89 \%$. Artinya, hanya terdapat beberapa siswa saja yang tidak mampu merencanakan atau menetukan strategi dengan benar. Selanjutnya kemampuan pemecahan masalah matematika siswa pada kategori sedang memperoleh nilai rata-rata 52.89 tergolong kategori sedang dan memiliki persentase $28.17 \%$. Artinya siswa mampu menentukan rumus yang digunakan namun kurang lengkap. Kemudian kemampuan pemecahan masalah matematika siswa pada kategori rendah memperoleh nilai rata-rata 30.00 tergolong kategori sedang dan memiliki persentase $29.03 \%$. Artinya siswa sudah merencanakan atau menetukan strategi tetapi kurang tepat sehingga belum memperoleh skor yang maksimal. 


\section{c. Melaksanakan penyelesaian}

Tabel 1 menunjukkan pada indikator melaksanakan penyelesaian dengan nilai rata-rata sebesar 42.83 tergolong kategori sedang dan memiliki pencapain persentase $19.78 \%$. Artinya siswa sudah mampu menyelesaikan masalah. Ada beberapa siswa yang menuliskan penyelesaian masalah dengan benar dan tepat, melaksanakan penyelesaian masalah dengan apa yang direncanakan sebelumnya. Selain itu, terdapat siswa dalam proses pengerjaannya masih ditemukan beberapa kesalahan seperti siswa salah dalam membagi, salah memasukkan angka yang diketahui. Hal ini terjadi karena beberapa siswa tidak mengikuti perintah soal seperti belum menuliskan apa yang diketahui, apa yang ditayakan, atau membuat strategi sehingga kurang teliti dalam pross pengerjaanya dan belum mendapatkan nilai yang sempurna.

Tabel 2 kemampuan pemecahan masalah matematika siswa untuk indikator melaksanakan penyelesaian pada tingkat kategori tinggi memperoleh nilai rata-rata 62.22 tergolong kategori sedang dan memiliki persentase $21.11 \%$. Serta kemampuan pemecahan masalah matematika siswa pada kategori sedang memperoleh nilai rata-rata 34.00 tergolong kategori sedang dan memiliki persentase 18.11\%. Artinya beberapa siswa sudah mampu melaksanakan penyelesaian masalah beserta perhitungannya dengan tepat dan ada juga beberapa siswa melaksanakan penyelesaian masalah beserta perhitungannya tetapi salah diakhir. Kemudian kemampuan pemecahan masalah matematika siswa pada kategori rendah memperoleh nilai rata-rata 20.56 tergolong kategori sedang atau memiliki persentase $19.89 \%$. Artinya, siswa melaksanakan rencana penyelesaian masalah beserta perhitungannya tetapi kurang tepat atau salah diakhir dan ada beberapa yang melaksanakan rencana penyelesaian beserta perrhitungannya dengan tepat.

\section{d. Memeriksa Kembali}

Tabel 1 menunjukkan pada indikator melaksanakan penyelesaian dengan nilai rata-rata sebesar 34.61 tergolong kategori sedang dan memiliki pencapain perentase $15.98 \%$. Artinya beberapa mahasiswa mampu memeriksa kembali. Terdapat juga mahasiswa yang belum menuliskan kesimpulan dan mencocokkan jawaban yang diperoleh dengan apa yang diketaui dan ditanyakan. Dan ada beberapa mahasiwa sudah menuliskan kesimpulan benar atau salah, akan tetapi tidak menuliskan pembuktian atau mencocokkan jawaban yang diperoleh dengan apa yang diketahui dan ditanyakan di soal.

Tabel 2 kemampuan pemecahan masalah matematika siswa untuk indikator memeriksa kembali pada tingkat kategori tinggi memperoleh nilai rata-rata 51.60 tergolong kategori sedang dan memiliki persentase $17.50 \%$. Artinya siswa sudah mampu menjelaskan dan memeriksa kembali yaitu mencocokkan jawaban yang diperoleh dengan apa yang diketahui dan ditanyakan. Terdapat juga mahasiswa hanya menjelaskan atau menuliskan kesimpulan dari jawaban yang diperoleh. Selanjutnya kemampuan pemecahan masalah matematika siswa pada kategori sedang memperoleh nilai rata-rata 
25.56 tergolong kategori sedang dan memiliki persentase $13.61 \%$. Artinya beberapa mahasiswa mampu menjelasakan atau memeriksa kembali jawaban yang diperoleh. Kemudian kemampuan pemecahan masalah matematika siswa pada kategori rendah memperoleh nilai rata-rata 15.56 tergolong kategori sedang dan memiliki persentase $15.05 \%$. Artinya mahasiswa mampu menuliskan kesimpulan dengan benar. Hal ini tidak jauh berbeda dengan mahasiswa tingkat pemecahan masalah sedang penyebabnya yaitu, mahasiswa hanya melakukan perhitungan saja tanpa memberikan jawaban akhir atau menjelaskan jawaban yang diperoleh sehingga nilai yang diperoleh sedang.

\section{KESIMPULAN}

Adapun kesimpulan penelitian ini berdasarkan uraian di atas adalah kemampuan pemecahan masalah dalam menyelesaikan masalah aljabar linear mahasiswa pada indikator memahami masalah masuk dalam kategori tinggi, merencanakan dan melaksanakan penyelesaian berkategori sedang serta memeriksa kembali masuk dalam kategori sedang dilihat dari nilai rata-rata per indikator.

\section{DAFTAR PUSTAKA}

Aini, R. N. (2014). Analisis Pemahaman Siswa SMP Dalam Menyelesaikan Masalah Aljabar pada PISA. Jurnal Ilmiah Pendidikan Matematika, 3(2).

Effendi, L. A. (2012). Pembelajaran Matematika dengan Metode Penemuan Terbimbing untuk Meningkatkan Kemampuan Representasi dan Pemecahan Masalah Matematis Siswa SMP. Jurnal Penelitian Pendidikan Universitas Pendidikan Indonesia, 13(2), 1-10.

Hidayatullah, A. 2018. Pembelajaran Matematika pada Era Media Sosial dan Budaya Pop. Jurnal Pendidikan Matematika, 1(1)1-12.

Kurniawan, R.I., Hepsi, N., \&Yani, S. (2010). Analisis Kemampuan Pemecahan Masalah Matematis dengan Menggunakan Pembelajaran Daring. Jurnal Inovasi dan Riset Pendidikan Matematika,1(2)

Misu, L. (2014). Mathematical Problem Solving Of Student by Approach Behaviour Lerning Theory. International Jurnal of Education And Research, 2(10), 181-188.

Nortvig, A.M. (2014). E-Learning In Poly-Topic Settings. Electronic Journal Of E-Learning. 12(2), 206-214.

Ulya, H., Kartono, \& Retnoningsih, A. (2014). Analysis Ofmathematics Problem Solving Ability Of Junior High Scholl Students Viewed From Students' Cognitive Style. International Conference On Mathematics, Science, And Education 2014 (ICMSE 2014). 2(10), 577-582.

Zahra. P. L. (2017). Strategi Mahasiswa dalam Menyelesaikan Permasalahan Kontekstual pada Materi Aljabar. Jurnal. Surakarta. 